\title{
РОЗДІМ 4
}

\section{Екомого-економічні пробцеми}

\section{Наукове обгрунтування підвищення техніко-економічної ефективності використання сонячної енергії,***}

\author{
Л. Г. МЕЛЬНИК ${ }^{i}$, O. I. МАЦЕНКО ${ }^{i i}$, В. С. ТЕРЕЩЕНКО
}

\begin{abstract}
Стаття присвячена пошуку шляхів підвищення ефективності використання сонячних панелей. У руслі підвищення економічної ефективності експлуатації сонячних станцій розглянуто способи зниження вартості виробництва електроенергії на основі енергії сонця. Метою статті $є$ дослідження шляхів більш ефективного використання сонячної енергії, а також порівняння всіх видів установки фотоелектричних модулів. Основний акцент у дослідженні зроблено на системи стеження за Сонцем, що дає накраще співвідношення ціна/ефективність сонячних станцій. Зокрема, досліджено питання економічної доцільності використання двовісної системи трекінгу сонячних панелей. Розглянуто переваги та недоліки даного підходу. Проаналізовано енергетичні можливості сонячного випромінювання в земних умовах. Побудовано таблицю залежностей кута руху Сонця в часі за одну світлову добу для умов Сумського регіону. Розраховано максимальне значення інтенсивності сонячного випромінювання за рік на $1 \mathrm{~m}^{2}$. Побудований графік середньомісячного виробництва електроенергії. В ході роботи було поставлено експеримент, в рамках якого розраховано чотири варіанти розміщення фотоелектричних модулів: $з$ автоматичним наведенням на Сонце; похилого типу; вертикального типу; із фіксованим кутом. Встановлено, що для міста Сум найбільш ефективною $\epsilon$ двовісна система орієнтування. За результатами обробки експериментальних даних в системі з трекером забезпечується вироблення електричної енергії майже на 24 \% більше порівняно із стаціонарним варіантом інсталяції (фіксованим кутом) модуля
\end{abstract}

\footnotetext{
${ }^{i}$ Мельник Леонід Григорович, доктор економічних наук, професор, завідувач кафедри економіки, підприємництва та бізнес-адміністрування Сумського державного університету, директор Науково-дослідного інституту економіки розвитку МОН України та НАН України у складі Сумського державного університету;

ii Маценко Олена Ігорівна, технік 1-ї категорії науково-дослідної частини кафедри економіки, підприємництва та бізнес-адміністрування Сумського державного університету;

iii Терещенко Владислав Сергійович, магістрант факультету електроніки та інформаційних технологій Сумського державного університету.

* Публікація містить результати досліджень, проведених у рамках науково-дослідних робіт «Розроблення фундаментальних основ відтворювального механізму соціально-економічного розвитку в ході Третьої промислової революції» (№ д/р 0118U003578), «Моделювання трансферу екоінновацій в системі «підприємство-регіон-держава»: вплив на економічне зростання та безпеку України» (№ д/p 0119U100364), що фінансуються за рахунок держбюджетних коштів МОН України.

** Публікація містить результати досліджень, проведених у рамках господарчого договору № 53.142020.СП/01 від 03 лютого 2020 р. «Підвищення конкурентоздатності підприємства на основі оптимального використання діджитал-платформ для просування промислової продукції».
}

(C) Л. Г. Мельник, О. І. Маценко, В. С. Терещенко, 2020.

https://doi.org/10.21272/mer.2020.88.10

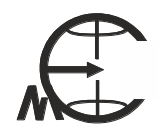


Л. Г. Мельник, О. І. Маценко, В. С. Терещенко. Наукове обгрунтування

підвищення техніко-економічної ефективності використання сонячної енергії

фотоелектричного модуля. Результати проведеного дослідження можуть бути використані енергетичними організаціями і підприємствами, органами влади та іншими зацікавленими сторонами у сфері альтернативної енергетики.

Ключові слова: ефективність, сонячна панель, електроенергія, трекерна система, фотоелектричний модуль.

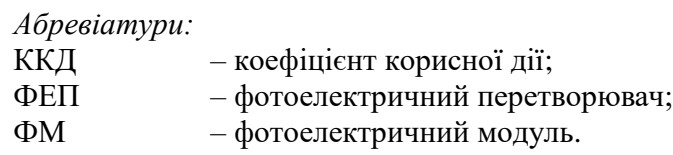

Вступ. У 2019 році використання сонячного випромінювання для цілей енергетики свідчило про економічну неефективність та комерційну непривабливість фотоелектричних модулів у сучасних цінових умовах без державних програм підтримки розвитку відновлювальної енергетики.

Зниження вартості виробництва електроенергії 3 енергії сонця можливе двома способами: зниженням вартості ФМ та підвищенням ефективності збору енергії. Реалізація першого способу можлива шляхом здешевлення виробництва фотоелектричних модулів або матеріалу геліоприймача. Що стосується другого способу, то підвищити ефективність можна, застосовуючи такі прийоми:

1. Використовувати багатошарові фотоприймачі на гетеропереходах, проте їх вартість набагато вища від звичайних. Тому співвідношення ціна/ефективність фактично не змінюється.

2. Застосовувати двосторонні фотоелектричні модулі, що незначно збільшує ефективність при значному збільшенні ціни.

3. Додавати різні концентратори, що збільшують фотовідповідь, але фотоелементи при цьому гріються, що негативно позначається на їх ККД і терміні експлуатації.

4. Обладнати фотоелементи системою стеження за Сонцем, що дає найкраще співвідношення вартість/ефективність.

На цьому етапі розвитку сонячної енергетики найбільш пильну увагу доцільно приділити останньому варіанту. Величиною, що впливає на вироблену потужність фотоелектричних модулів, є кут падіння сонячних променів на її поверхню. Навіть при найефективнішій стаціонарній установці фотоелектричних модулів програш у вироблюваній потужності становить до $50 \%$, порівнюючи з безперервним орієнтуванням на Сонце. Застосування систем спостереження дозволить змінювати кут нахилу фотоелектричних модулів упродовж дня таким чином, щоб зберігати прямий кут падіння сонячних променів на його поверхню. Це дозволить збільшити кількість потужності, що надійшла, а отже, і кількість виробленої потужності. Цей спосіб підходить для вже працюючих СЕС, для цього потрібно лише змінити опорну конструкцію $[1,2,3,4,5]$.

Аналіз останніх досліджень та публікацій. Дослідженню різних систем встановлення ФЕП приділяли увагу як зарубіжні, так і вітчизняні вчені, зокрема Роберт Сант' Ансельмо, Арнольд Стівен Арч, В. Н. Кулешов, Л. А. Молохина, Э. А. Нарусбек, С. А. Філін, Г. Р. Філіна, В. І. Ямпольський. Науковці досліджували різні методи встановлення ФЕП для збільшення виробництва електроенергії. Проте, це питання і до цього часу не втратило актуальності в Україні та потребує подальшого вивчення. 
Leonid Hr. Melnyk, Olena I. Matsenko, Vladyslav S. Tereshchenko. Scientific Substantiation of Increase of Technical and Economic Efficiency of Use of Solar Energy

Метою статті є дослідження шляхів підвищення техніко-економічної ефективності використання сонячної енергії.

Результати дослідження. Обсяг виробленої електроенергії зростає завдяки застосуванню сонячного трекера через збільшення кількості сонячної енергії, що потрапляє на модуль. Для перетворення сонячної енергії в електричну використовується сонячна панель. Сонячна панель забезпечує живленням контролер заряду, який, у свою чергу, накопичує енергію в акумуляторних батареях. Оскільки найбільш ефективне використання сонячної енергії досягається завдяки напрямку променів перпендикулярно до сонячної панелі, необхідно обертати її в різні напрямки залежно від часу доби. Для цього використовується так званий сонячний трекер.

Сонячний трекер складається $з$ механічної системи пересувань, електродвигунів і електронної системи контролю двигунами.

Сонячний трекер у повній комплектації містить такі елементи:

1. Несуча конструкція, що складається з фіксованої та рухомої частин, рухома частина має дві осі обертання.

2. Система орієнтації (позиціонування) рухомої частини трекера, що складається 3 електродвигунів і пристрою управління ними.

3. Система управління i інтерфейсу, призначені для управління, контролю i обслуговування енергосистеми.

Конструктив трекера повинен забезпечувати здатність витримувати сильні вітрові навантаження під час його роботи в складі енергосистеми. Зі збільшенням розмірів робочої поверхні корисного навантаження збільшується парусність комплексу. Вага корисного навантаження теж має значення. Тому проектувальникам часто доводиться у своїх рішеннях перерозподіляти навантаження на трекер, збільшуючи габарити системи $[6,7]$.

Математична модель ФЕП. За допомогою значно поширених кристалічних сонячних модулів можна перетворити сонячну енергію на електрику з ефективністю $14-17^{\circ} \%$. Електроенергетичні можливості таких ФЕП знаходяться в межах 110-170 Вт/м ${ }^{2}$ при оптичній інтенсивності 1 кВт/м². Фотоелементи промислових сонячних батарей мають ефективну робочу площу $S_{e q}$ від $1,2 \mathrm{~m}^{2}$ до $1,9 \mathrm{~m}^{2}$, яка пропорційна відсотку отриманої енергії. Одним з основних показників ефективності залежно від ККД $\epsilon$ величина виходу на одиницю площі $\left(\mathrm{BT} / \mathrm{M}^{2}\right)$. Цей показник характеризує енергетичну ефективність і компактність геометричних розмірів сонячних панелей.

Вихідна потужність модуля ФЕП буде пропорційна прийнятій інтенсивності оптичної потужності сонця $I_{\text {opt }}$. $\left(I_{\text {opt }}=P_{\text {opt }} / S, \mathrm{BT} / \mathrm{M}^{2}\right)$, величині коефіцієнта корисної дії перетворення, коефіцієнта поглинання $k$, ефективній площі $\mathrm{S}_{\mathrm{ef}}$, а також косинусу кута падіння $\alpha,(1)$ :

$$
P_{F E P}=I_{F E P} * U_{F E P}=\eta * K_{t} * k * I_{o p t} * S_{e f} * \cos \alpha,
$$

де $I_{F E P}, U_{F E P}$ - робочі напруга та струм фотоелектричного модуля; $\eta$ - коефіцієнт корисної дії перетворення; $I_{\text {opt }}$ - інтенсивності оптичного випромінювання; $k$ коефіцієнт поглинання, $k=0,8-0,98 ; S_{e f}-$ ефективна площа поверхні модуля; $\alpha-$ кут падіння світлових променів, $0-90^{\circ} \mathrm{C} ; K_{t}-$ температурний коефіцієнт, взимку ближче до 0,7 , влітку $K_{t}$ наближається до 0,5 .

Для більш ефективного перетворення кут падіння $\alpha$ випромінювання на активну поверхню повинен максимально наближатися до $90^{\circ}$, що відповідає умові максимального перетворення при $\cos 90^{\circ}=1$. Формула (1) при цьому матиме вигляд (2): 
Л. Г. Мельник, О. І. Маценко, В. С. Терещенко. Наукове обгрунтування

підвищення техніко-економічної ефективності використання сонячної енергії

$$
P_{F E P}=\eta * K_{t} * k * I_{o p t} * S_{e f} \bullet
$$

Ефективність та ККД у не слідкуючих за Сонцем ФЕП (в яких не передбачено автоматичного наведення на Сонце) помітно змінюються упродовж доби і можуть зменшуватися на 30-40\% від максимального значення на відміну від трекерних сонячних систем, які шляхом повороту та радіального переміщення ФЕП забезпечують умову $\alpha=0^{\circ}$, оскільки при куті падіння, що не дорівнює $90^{\circ}$, косинус кута в (1) змінюється від 0,3 до 1 та викликає відповідне зменшення ефективної вихідної потужності РFЕР.

Ефективність перетворення сонячної енергії значною мірою зменшується через відносно велике значення відбивання від поверхні ФЕП.

Коефіцієнт корисної дії (ККД) ФЕП (ефективність перетворення) світлової енергії на електричну емпірично визначається за формулою (3):

$$
\eta=\frac{P_{\text {elect }}}{P_{\text {optic }}} * \gamma * 100 \% \approx \frac{I_{r} U_{r}}{\Phi * S * \sin \varphi} * \gamma * 100 \%,
$$

де $I_{r}, U_{r}$ - робочі електричні струм та напруга; $\Phi$ - світловий потік; $S$ - площа активної поверхні; $\varphi$ - кут падіння променів; $\gamma$ - коефіцієнт квантової ефективності та провідності; $P_{\text {elect }}, P_{\text {optic }}$ - електрична та оптична потужності.

Аналіз енергетичних можливостей сонячного випромінювання в земних умовах

Потік сонячного випромінювання, що проходить через площу розміром $1 \mathrm{~m}^{2}$ на вході в атмосферу Землі, розташовану перпендикулярно дорівнює в середньому 1367 Вт/м². Через поглинання при проходженні атмосфери Землі середній у Європі потік сонячного випромінювання становить $1020 \mathrm{BT} / \mathrm{M}^{2}$. Але враховуючи, що значення потоку сонячного випромінювання через одиничну горизонтальну площу змінюється протягом доби, то середньодобове значення є як мінімум у 3 рази меншим (через зміну дня і ночі і зміну кута сонця над обрієм). Узимку в помірних широтах це значення у 2 рази менше. Карту потужностей, отриманих від фотоелектричного перетворення сонячного випромінювання, наведено на рис. 1.

Доцільність сонячного трекера в ФЕП. Дієвим шляхом підвищення ефективності використання ФЕП $є$ забезпечення автоматичної корекції кута падіння сонячних променів на поверхню ФЕП шляхом використання слідкуючих трекерних систем. Для перевірки був проведений практичний експеримент на базі сонячних панелей загальною потужністю 3000 кВт.

Як відомо, значення кута падіння $\alpha$ можна визначити за положенням Сонця (а також тіні від предметів) у визначений час доби. Для Сумського регіону лінія руху Сонця над горизонтом знаходиться у південній півкулі (південний напрямок), що визначає необхідну орієнтацію модулів ФЕП, суворо на південь. Наприклад, о $7^{00}$ ранку тінь від перпендикулярного до поверхні Землі лінійного предмета буде спрямована суворо на захід; о $13^{00}$ ця тінь буде направлена на північ; а о $19^{00}$ - на схід. Цей принцип (визначення азимута) покладено в основу роботи сонячного годинника, відомого ще багато тисячоліть тому. Із цього випливає, що середній час руху Сонця над горизонтом дорівнює 12 год із центром, що припадає на $13^{00}$ годину. Саме на цей центр $\left(13^{00}\right)$ год і припадають максимально ефективні умови падіння променів - кут падіння до перпендикуляра поверхні ФЕП наближається до 00 (кут по відношенню до нормалі). При цьому слід відмітити, що по відношенню до поверхні Землі модулі ФЕП промислово встановлюють 
Leonid Hr. Melnyk, Olena I. Matsenko, Vladyslav S. Tereshchenko. Scientific Substantiation of Increase of Technical and Economic Efficiency of Use of Solar Energy

під кутом $\sim 45^{\circ}$, що відповідає куту нахилу Сонячних променів над горизонтом $\left(\sim 45^{\circ}-45^{\circ} \approx 0^{\circ}\right)$.

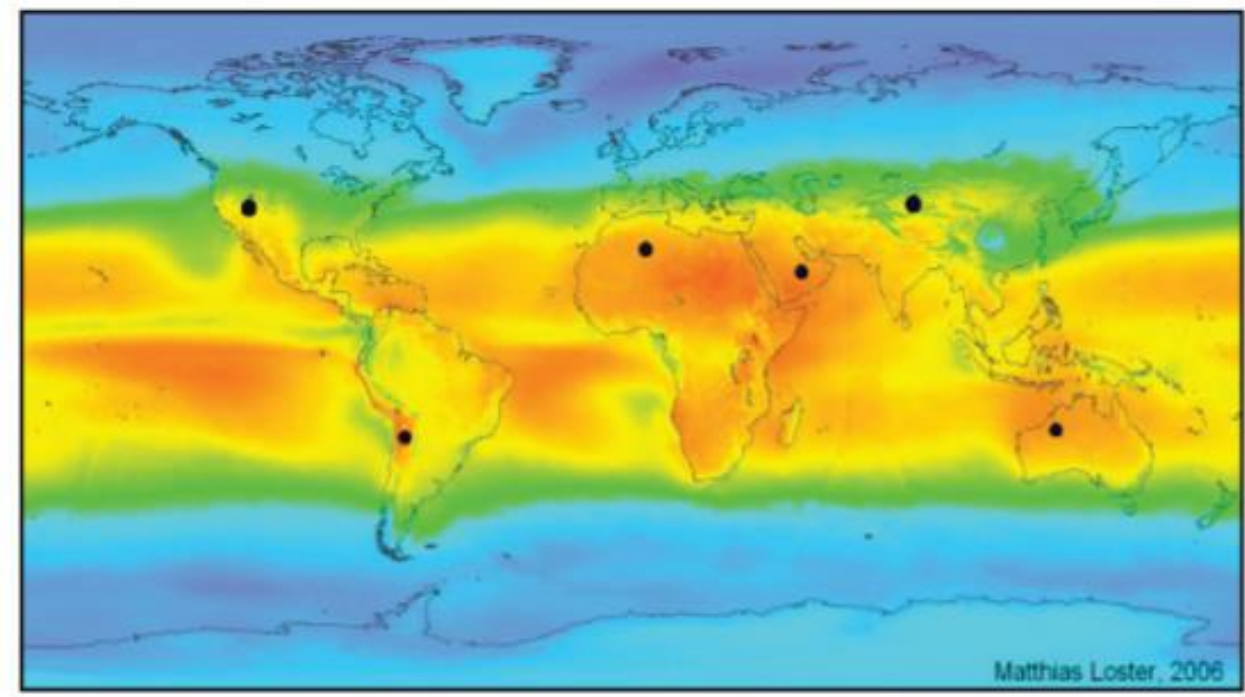

$\begin{array}{llllllll}0 & 50 & 100 & 150 & 200 & 250 & 300 & 350 \quad \mathrm{~W} / \mathrm{m}^{2}\end{array}$

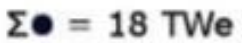

Рис. 1. Карта енергетичного виходу ФЕП з середнім ККД = 14 \% (чорними крапками показано основні центри, що виробляють переважну більшість сонячної енергії світу із сумарним значенням 18 ТВт)

Розділивши повну траєкторію руху Сонця у площині 1800 на 12 год, отримуємо кут $15^{\circ}$, що відповідає 1-й годині часу руху Сонця над горизонтом. Тобто через кожну годину тілесний кут руху сонячного диска над обрієм (азимут) буде змінюватись на $15^{\circ}$. Побудуємо таблицю залежностей кута руху Сонця в часі за одну світлову добу (табл. 1).

Таблиия 1

Залежність азимута від часу в одній світловій добі*

\begin{tabular}{|c|c|c|c|}
\hline & Час світлової доби & $\begin{array}{c}\text { Радіальний кут падіння } \\
\text { (азимут) променів Сонця }\end{array}$ & $\begin{array}{c}\text { Кут до нормалі поверхні } \\
\text { ФЕП }\end{array}$ \\
\hline 0 & $7: 00$ & $0^{\circ}$ & $90^{\circ}$ \\
\hline 1 & $8: 00$ & $15^{\circ}$ & $65^{\circ}$ \\
\hline 2 & $9: 00$ & $30^{\circ}$ & $45^{\circ}$ \\
\hline 3 & $10: 00$ & $45^{\circ}$ & $30^{\circ}$ \\
\hline 4 & $11: 00$ & $60^{\circ}$ & $15^{\circ}$ \\
\hline 5 & $12: 00$ & $75^{\circ}$ & $00^{\circ}$ \\
\hline 6 & $13: 00$ & $90^{\circ}$ & $-15^{\circ}$ \\
\hline 7 & $14: 00$ & $105^{\circ}\left(-15^{\circ}\right)$ & $-30^{\circ}$ \\
\hline 8 & $15: 00$ & $120^{\circ}\left(-30^{\circ}\right)$ & $45^{\circ}$ \\
\hline 9 & $16: 00$ & $135^{\circ}\left(-45^{\circ}\right)$ & $-60^{\circ}$ \\
\hline 10 & $17: 00$ & $150^{\circ}\left(-60^{\circ}\right)$ & $-75^{\circ}$ \\
\hline 11 & $18: 00$ & $165^{\circ}\left(-75^{\circ}\right)$ & $-90^{\circ}$ \\
\hline 12. & $19: 00$ & $180^{\circ}\left(0^{\circ}\right)$ & \\
\hline
\end{tabular}


Л. Г. Мельник, О. І. Маценко, В. С. Терещенко. Наукове обгрунтування підвищення техніко-економічної ефективності використання сонячної енергії

*у таблиці не враховано зміну кута нахилу $\beta$ по відношенню до вертикального напрямку (середнє знач цього кута $45^{\circ}$ ), але вертикальний кут змінюється в залежності від пори року: найменший взимку $\left(15-20^{\circ}\right)$ найбільший - влітку $\left(40-45^{\circ}\right)$.

Якщо врахувати вертикальний кут $\beta$, то формула набере вигляду:

$$
P_{F E P}=I_{F E P} * U_{F E P}=\eta * k * I_{o p t} * S_{e f} * \cos \alpha * \cos (\varphi-\beta),
$$

де $\phi$ - кут нахилу модуля ФЕП (сонячної батареї) до поверхні землі.

Формула (4) є найбільш повною математичною моделлю, що описує роботу сонячних батарей і ФЕП у земних умовах. Різниця кутів $(\phi-\beta)$ визначає кут між перпендикуляром поверхні (нормаллю) ФЕП і безпосередньо напрямом (вектором падіння) сонячних променів. Але, як правило, на практиці у більшості фотоенергетичних системах кут нахилу модуля $\phi$ застосовують наближеним до $45^{\circ}$, що передбачає майже вертикальне падіння променів на поверхню ФЕП [8].

Розрахунок максимального значення інтенсивності сонячного випромінювання

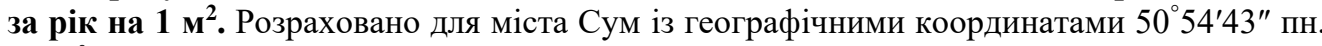
ш. $34^{\circ} 48^{\prime} 12^{\prime \prime}$ сх. д.

Беремо сонячну радіацію середню за добу в кВт*год./(м²*добу) із джерел NASA [9].

Таблиия 2

\begin{tabular}{|c|c|c|c|c|c|c|c|c|c|c|c|c|}
\hline $\begin{array}{c}\text { Lat } \\
50.92 \\
\text { Lon } \\
34.12\end{array}$ & $\stackrel{0}{\stackrel{1}{0}}$ & 罗 & 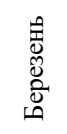 & $\stackrel{\theta}{\stackrel{\theta}{0}}$ & $\begin{array}{l}\text { 㞌 } \\
\text { है } \\
\text { है }\end{array}$ & 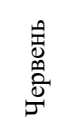 & 焉 & 㠰 & $\begin{array}{l}\text { 焉 } \\
\text { Dे } \\
\text { Dी }\end{array}$ & 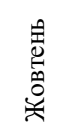 & 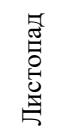 & 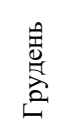 \\
\hline $\begin{array}{c}\text { 22- } \\
\text { річна } \\
\text { середня }\end{array}$ & 1,14 & 1,93 & 3,05 & 3,98 & 5,27 & 5,32 & 5,38 & 4,67 & 3,19 & 1,98 & 1,10 & 0,86 \\
\hline
\end{tabular}

Сонячна радіація за рік

$$
\mathrm{E}_{\mathrm{pi \kappa}}=\sum_{i=1}^{12} \mathrm{E}_{i}=38130 \kappa \mathrm{BT} * \mathrm{M}^{2},
$$

де $E_{p i \kappa}-$ значення потоку сонячної радіації.

Наближене значення виробленої електроенергії за рік за допомогою ФЕП із ККД $14 \%$, тобто $\mathrm{k}=0,14$ :

$$
P_{\text {наб }}=\mathrm{E}_{\text {рік }} \cdot k=38130 \cdot 0.14=5338,2 \text { кВт } / \text { рік },
$$

\section{Проведення експериментального дослідження параметрів ФЕП}

У ході досліду було розраховано чотири варіанти встановлення ФЕП

1. 3 автоматичним наведенням на Сонце (за допомогою застосування спеціального геліотрекера на мікроконтролер Arduino).

2. Розміщення ФЕП похилого типу.

3. Розміщення ФЕП вертикального типу. 
Leonid Hr. Melnyk, Olena I. Matsenko, Vladyslav S. Tereshchenko. Scientific Substantiation of Increase of Technical and Economic Efficiency of Use of Solar Energy

4. Розміщення ФЕП із фіксованим кутом.

Можна зазначити, що оптимальним із точки зору отримання максимального виробництва електроенергії за допомогою сонячних батарей є використання ФЕП на базі слідкуючих (трекерних) систем (рис. 2), що збільшують оптичний потік на сонячні панелі. Це дозволить отримати максимальне використання енергетичного ресурсу сонячних панелей.

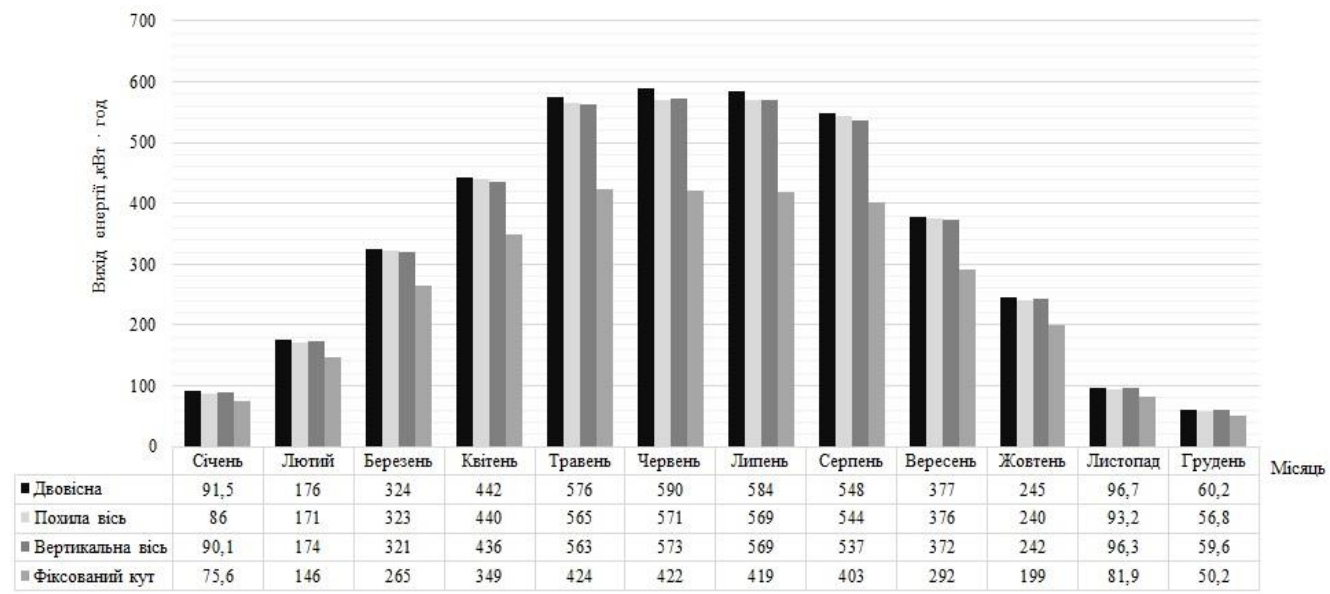

Рис. 2. Графік середньомісячного виробництва електроенергії

Як показують результати обробки експериментальних даних, у слідкуючій системі забезпечується вироблення електричної енергії майже на $24 \%$ більше порівняно із стаціонарним варіантом інсталяції (фіксованим кутом) модуля ФЕП.

Це дозволить отримати максимальне використання енергетичного ресурсу сонячних панелей i, як наслідок, з економічної точки зору - зменшити строк їх окупності.

Висновки. Розглянуто використання найбільш ефективних способів підвищення продуктивності сонячних панелей, кращим з яких визначено спосіб орієнтування сонячних панелей за допомогою сонячних трекерів.

Для міста Сум розраховано, що найбільш ефективною $\epsilon$ двовісна система орієнтування, яка є більш економічно обгрунтованою для використання, ніж сонячні панелі без систем орієнтування або з одновісною системою.

Запропонована конструкція є відносно недорогою і надійною і дозволяє за допомогою наведеного алгоритму досить точно орієнтувати панелі на сонце за двома осями - за кутом місця і азимутом.

\section{Література}

1. Шиняков, Ю. А., Шурыгин Ю. А., Аркатова О. Е. Повышение энергетической эффективности автономных фотоэлектрических энергетических установок // Электроника, измерительная техника, радиотехника и связь. Доклады ТУСУРа. - № 2 (22). - Часть 2. - 2010. - С. 102.

2. Попель, $О . C$. К расчету поступления солнечной радиации на земную поверхность / О. С. Попель, С. Е. Фрид, Г. М. Альварес // Гелиотехника. - 1986. - №1. - С.56. 
3. Плеханов, С. И. Оценка возможностей роста производства солнечных элементов на основе $\mathrm{CdTe}$, CIGS и GaAs/Ge в период 2010-2025 гг. [Электронный ресурс] / С. И. Плеханов, А. В. Наумов. - Режим доступа : AEnergy.ru

4. Наумов, А. В. Развитие солнечной энергетики на основе тонкопленочных CIGS-элементов / А. В. Наумов, С. И. Плеханов // Энергия: экономика, техника, экология. - 2013. - № 7. - С. 14.

5. Кузнецов, Ф.А. Кремний для солнечной энергетики / Ф. А. Кузнецов, М. Ф. Резниченко // Материалы электронной техники. - 2008. - №4. - С. 4.

6. Gay, C.F. Performance advantages of two-axis tracking for large flat-plate photovoltaic energy systems / C. F. Gay, J. W. Yerkes, J. H. Wilson // Conf. Rec. IEEE Photovoltaic Spec. Conf 16. - 1982.

7. Капля, E. В. Автоматическая система ориентации солнечной батареи в условиях переменной освещенности / Е. В. Капля // Известия ВолгГТУ. - 2009.- №8(56) - С. 88.

8. UST [Электронный ресурс]. - Режим доступа: http://ust.su/solar/media/section-inner79/3032

9. NASA Surface meteorology and Solar Energy [Electronic resource]. - Access mode: https://eosweb.larc.nasa.gov/cgi-bin/sse/grid.cgi?uid=3030

Отримано 22.01.2020 p

\title{
Научное обоснование повышения технико-экономической эффективности
} использования солнечной энергии

\section{ЛЕОНИД ГРИГОРЬЕВИч МЕЛЬНИК*, ЕЛЕНА ИГОРЕВНА МАЦЕНКО**, ВЛАДИСЛАВ СЕРГЕЕВИч ТЕРЕЩЕНКо}

\author{
* доктор экономических наук, профессор, заведуюший кафедры экономики, \\ предпринимательства и бизнес-администрирования Сумского государственного университета, \\ директор Научно-исследовательского института экономики развития МОН Украины и НАН \\ Украины в составе Сумского государственного университета, \\ ул. Р.-Корсакова, 2, г. Сумы, 40007, Украина, \\ тел.: 00-380-542-332223, e-mail: melnyk@econ.fem.sumdu.edu.ua \\ ** техник 1-й категории научно-исследовательской части кафедры экономики, \\ предпринимательства и бизнес-администрирования Сумского государственного университета, \\ ул. Р.-Корсакова, 2, г. Сумы, 40007, Украина, \\ тел.: 00-380-542-332223, e-mail: ol.matsenko@econ.sumdu.edu.ua \\ **** магистрант факультета электроники и информационных технологий \\ Сумского государственного университета, \\ ул. Р.-Корсакова, 2, г. Сумы, 40007, Украина, \\ тел.: +380-66-1996680, e-mail: vladtereschenko@ukr.net
}

Статья посвящена поиску путей повышения эффективности использования солнечных панелей. В русле повышения экономической эффективности эксплуатации солнечных станций рассмотрены способы снижения стоимости производства электроэнергии на основе энергии солнца. Целью статьи является исследование путей более эффективного использования солнечной энергии, а также сравнение видов установки фотоэлектрических преобразователей. Основной акцент в исследовании сделан на системы слежения за Солнцем, что дает лучшее соотношение цена/эффективность солнечных станций. В частности, исследованы вопросы экономической целесообразности использования двухосных системы трекинга солнечных панелей. Рассмотрены преимущества и недостатки данного подхода. Проанализированы энергетические возможности солнечного излучения в земных условиях. Построено таблицу зависимостей угла движения Солнца во времени за одни световые сутки для условий Сумского региона. Рассчитано максимальное значение интенсивности солнечного излучения за год на 1 м2. Построен график среднемесячного 
Leonid Hr. Melnyk, Olena I. Matsenko, Vladyslav S. Tereshchenko. Scientific Substantiation of Increase of Technical and Economic Efficiency of Use of Solar Energy

производства электроэнергии. В ходе работы был поставлен эксперимент, в рамках которого рассчитаны четыре варианта размещения фотоэлектрических преобразователей: с автоматическим наведением на Солнце; наклонного типа; вертикального типа; с фиксированным углом. Установлено, что для города Сумы наиболее эффективна двухосная система ориентирования. По результатам обработки экспериментальных данных в системе с трекером обеспечивается выработка электроэнергии почти на 24\% больше по сравнению со стационарным вариантом инсталляции (фиксированным углом) модуля фотоэлектрического преобразователя. Результаты проведенного исследования могут быть использованы энергетическими организациями и предприятиями, органами власти и другими заинтересованными сторонами в сфере альтернативной энергетики.

Ключевые слова: эффективность, солнечная панель, электроэнергия, трекерная система, фотоэлектрический модуль.

\title{
Mechanism of Economic Regulation, 2020, No2, 121-130 ISSN 1726-8699 (print)
}

\section{Scientific Substantiation of Increase of Technical and Economic Efficiency of Use of Solar Energy}

\author{
LEONID HR. MELNYK", \\ OLENA I. MATSENKO ${ }^{* *}$, \\ VLADYSLAV S. TERESHCHENKO***
}

*Dr. (Economics), Professor, Head of Department of Economics, Entrepreneurship and BusinessAdministration, Director of Research Institute for Development Economics (IDE) at Sumy State University, Ministry of Education and Science of Ukraine, National Academy of Science of Ukraine, R.-Korsakova Str., 2, Sumy, 40007, Ukraine,

phone:00-380-542-332223,e-mail:melnyk@econ.fem.sumdu.edu.ua

${ }^{* *}$ Technician of the 1st Category of the Research Part of the Department of Economics, Entrepreneurship and Business Administration, Sumy State University

R.-Korsakova Str., 2, Sumy, 40007, Ukraine,

phone:00-380-542-332223,e-mail: ol.matsenko@econ.sumdu.edu.ua
${ }^{* * *}$ Master Student of the Faculty of Electronics and Information Technologies, Sumy State University R.-Korsakova Str., 2, Sumy, 40007, Ukraine,
phone: +380-66-1996680, e-mail: vladtereschenko@ukr.net

Manuscript received 22 January 2020

The article is devoted to finding ways to improve the efficiency of using solar panels. In the mainstream of increasing the economic efficiency of solar stations' operation, methods of reducing the cost of generating electricity based on solar energy are considered. The purpose of the article is to study ways of more efficient use of solar energy and compare the types of installation of photovoltaic converters. The study's main focus is on solar tracking systems, which give the best price/efficiency ratio for solar stations. In particular, the economic feasibility of using a biaxial tracking system for solar panels has been investigated. The advantages and disadvantages of this approach are considered. The energy potential of solar radiation under terrestrial conditions is analyzed. A table of dependences of the angle of motion of the Sun in time for one light day for the conditions of the Sumy region was built. The maximum value of the intensity of solar radiation per year per $1 \mathrm{~m} 2$ is calculated. The graph of the average monthly electricity production was built. In the course of the work, an experiment was set up, within the framework of which four options for photoelectric converters' placement were calculated: with automatic guidance to the Sun; inclined type; vertical type; with a fixed angle. It has been established that for the city of Sumy a two-axis 
orientation system is most effective. According to the results of processing the experimental data, the system with the tracker provides almost $24 \%$ more power generation than the stationary installation option (fixed angle) of the photoelectric converter module. Energy organizations and enterprises can use the study results, authorities and other stakeholders in the field of alternative energy.

Keywords: efficiency, solar panel, electricity, tracker system, photovoltaic module.

JEL Codes: Q21, Q40

Figures: 2; Tables: 2; Formulas: 6 References: 9

Language of the article: Ukrainian

References

1. Shyniakov, Yu. A., Shuryhyn, Yu. A. \& Arkatova, O. E. (2010). Povysheniye energeticheskoy effektivnosti avtonomnykh fotoelektricheskikh energeticheskikh ustanovok [Increasing the energy efficiency of autonomous photoelectric power plants]. Elektronika. Izmeritelnaya Tekhnika. Radiotekhnika i Svyaz. Doklady TUSURa. - Electronics, measurement equipment, radio engineering and communications. Proceedings of TUSUR University, 2 (22), 2, 102. [in Russian].

2. Popel, O. S., Fryd, S. E. \& Alvares, H. M. (1986). K raschetu postupleniya solnechnoy radiatsii na zemnuyu poverkhnost [To the calculation of solar radiation input to the earth's surface]. Geliotechnika, 1, 56. [in Russian].

3. Plekhanov, S. Y. \& Naumov, A. V. Otsenka vozmozhnostey rosta proizvodstva solnechnykh elementov na osnove CdTe. CIGS i GaAs/Ge v period 2010-2025 gg. [Assessment of the possibilities of growth in the production of solar cells based on CdTe, CIGS and GaAs/Ge in the period 20102025]. Retrieved from AEnergy.ru [in Russian].

4. Naumov, A. V. \& Plekhanov, S. Y. (2013). Razvitiye solnechnoy energetiki na osnove tonkoplenochnykh CIGS-elementov [Development of solar energy based on thin-film CIGSelements]. Enerhyia Ekonomyka Tekhnyka Ekolohyia, 7, p. 14. [in Russian].

5. Kuznetsov F. A. \& Reznychenko M. F. (2008). Kremnyi Dlia Solnechnoi Enerhetyky [Silicon for solar energy]. Materyaly Elektronnoi Tekhnyky - Materials of Electronics Engineering, 4, p. 4. [in Russian]

6. Gay C. F., Yerkes J. W. \& Wilson J. H. (1982). Performance advantages of two-axis tracking for large flat-plate photovoltaic energy systems. Conf. Rec. IEEE Photovoltaic Spec. Conf. 16.

7. Kaplia, E. V. (2009). Avtomaticheskaya sistema oriyentatsii solnechnoy batarei v usloviyakh peremennoy osveshchennosti [Automatic orientation system of the solar battery under variable illumination conditions]. Izvestiya VolgGTU, 8(56), p. 88. [in Russian].

8. UST. http://ust.su/solar/media/section-inner79/3032.

9. NASA Surface meteorology and Solar Energy. Retrieved from https://eosweb.larc.nasa.gov/cgibin/sse/grid.cgi?uid=3030. 